\title{
ALBERTA'S COURT OF NEXT-TO-LAST RESORT: Appeals from the Alberta Court of Appeal to the Supreme Court of Canada, 1970-1990
}

\author{
PETER McCORMICK*
}

This paper reports the results of a statistical survey of the success rates of appeals to the Supreme Court of Canada. Appeals from all provinces were examined, but in his analysis Professor McCormick focuses on the Alberta Court of Appeal. The variables he discusses include the geographic and political composition of the Supreme Court, the mix of cases from different areas of the law, the length of experience of Court of Appeal judges, and the presence or absence of dissenting opinions.
Le présent article rapporte les taux de succès des appels interjetés auprès de la Cour suprême du Canada. Bien que l'enquête porte sur toutes les provinces, le professeur McCormick s'attache tout particulièrement aux résultats de la cour d'appel de l' Alberta et examine diverses variables -- composition géographique et politique de la Cour suprême. distribution des cas par secteur juridique, expérience des juges de la cour d'appel, présence ou absence d'opinions divergentes.

\section{TABLE OF CONTENTS}

I. INTRODUCTION $\ldots \ldots \ldots \ldots \ldots \ldots \ldots \ldots \ldots \ldots \ldots \ldots$

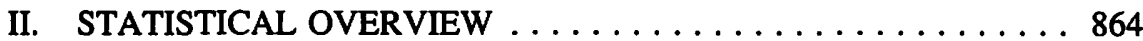

III. FREQUENCY OF APPEALS $\ldots \ldots \ldots \ldots \ldots \ldots \ldots \ldots \ldots 865$

IV. LASKIN AND THE OTHERS:

SUCCESS RATES PAST AND PRESENT . . . . . . . . 867

V. CORRELATES OF SUPREME COURT REVERSAL $\ldots \ldots \ldots 872$

VI. WHO VOTES TO REVERSE?

THE JUDGES OF THE S.C.C. AND ALBERTA APPEALS . . . . 874

VII. WHO GETS REVERSED? THE JUDGES OF

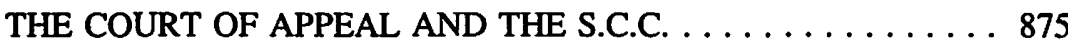

VIII. SUMMARY OF FINDINGS $\ldots \ldots \ldots \ldots \ldots \ldots \ldots \ldots \ldots 877$

\section{INTRODUCTION}

Within the Canadian judicial system, the Alberta Court of Appeal functions as an intermediate appeal court - that is, a court whose caseload consists overwhelmingly of appeals from the decisions of "lower" courts of original jurisdiction, but whose decisions are themselves subject to appeal to a "higher" court. ${ }^{1}$ As such, it can tend conceptually to get caught in the middle. On the one hand, there is the Supreme Court of Canada at

Professor, Department of Political Science, University of Lethbridge. This paper is the product of a larger project jointly funded by the Manitoba Legal Research Institute and the Alberta Law Foundation. I wish to acknowledge my appreciation for the encouragement and support of Prof. Alvin Esau, President of the MLRI; and for the conscientious and efficient work of Ms. Suzanne Maisey, my research assistant.

1. "Intermediate appeal court" is usually taken to refer to a court such as Ontario's former Divisional Court; in this paper, however, the term is used in the more general sense that would allow us, for example, to call the Supreme Court before 1949 an intermediate appeal court vis-d-vis the Judicial Committee of the Privy Council. 
the apex of the pyramid, which can over-rule any provincial court of appeal and whose decision thereafter constitutes binding precedent; this is especially true in Canada, where the Supreme Court is (under the terms of Section 101 of the Constitution Act, 1867) a "general court of appeal" and enjoys the final voice on all legal disputes and issues. ${ }^{2}$ On the other hand are the high-volume trial courts, more interesting by far to those who find the "real" impact of law where judicial system and general public interact directly. ${ }^{3}$

Simple logic, however, suggests the important role that flows from this middle position; linking the trial courts, with their millions of cases each year, to the Supreme Court of Canada, with its annual caseload measured in the dozens, the provincial courts of appeal collectively play an important gate-keeping and law-making role. This study will examine one such court - the Alberta Court of Appeal ${ }^{4}$ - in terms of one dimension of this middle role - namely the success rates for appeals from the Alberta Court of Appeal to the Supreme Court of Canada.

The traditional and orthodox focus of analysis is the substantive legal doctrine established or modified in the resolution of any specific appeal; the concern here is rather the general statistical background against which these appeals take place and of which they form a part. Logically, one cannot know what importance to attach to the outcome of a single appeal without knowing what the "normal" or "typical" result looks like - that is, the more frequently the Supreme Court reverses the provincial courts of appeal, the lower the information content (and the less the implicit criticism) of any specific reversal. Nor can one generalize casually from overall reversal rates, as if every appeal starts even and enjoys a level playing field. The success rates in specific areas of law (criminal as opposed to, say, family law) may differ significantly, and the mix of cases appealed may vary from one province to another without averaging out over time.

Any appeal court exercises a supervisory role over the courts whose decisions can be appealed to it. This goes well beyond the correction of simple error; higher courts are also expected to establish uniformity where lower courts differ on precise meanings or applications, and to show innovative doctrinal leadership as the judicial system responds to changing circumstances and demands. From this it follows that reversal by a higher court is seldom like a teacher correcting a math problem ("the lower court should have known..."), and more often simply the latest phase of an ongoing debate within the judiciary itself about the appropriate way for the courts to go. Consequently, lower court decisions are guided by a multiplicity of considerations of which "looking over the shoulder" at the next court in the hierarchy is only one, and not necessarily the most important one. As well, it is surely common sense rather that subversion to suggest that

2.

Unlike the U.S., where state supreme courts are final on questions of state law, and the supremacy of the U.S. Supreme Court comes into play only on questions of federal or constitutional law.

3. See e.g. Susan Silbey, "Making Sense of the Lower Courts" (1981) 6 Justice System Journal; and Austin Sarat, "Judging in the Trial Courts: An Exploratory Study" (1977) 39 Journal of Politics.

4. Alberta's highest court changed its name in 1979 (almost the mid-point of the period considered) from "Supreme Court of Alberta, Appellate Division" to "Alberta Court of Appeal," the latter style now being by far the most common in Canada; for convenience, the more recent name will be employed throughout. 
on any objective criteria of excellence, the strongest conceivable panel in a specific provincial court of appeal may sometimes be better than the weakest conceivable panel of Supreme Court judges, at which point the overtones of reversal become problematic. ${ }^{5}$

The point of this study is not to point fingers of criticism or to construct facile league tables of ability. It is simply to examine on a statistical basis the general outlines and changing patterns of the Supreme Court's exercise of its supervisory role over the provincial courts of appeal in general and the Alberta Court of Appeal in particular during two particularly critical decades ${ }^{6}$ in the evolution of the Canadian judicial system. The extent to which the Supreme Court uses its power of review (most specifically its power of reversal, altering the pattern of provincial appeal court decisions by establishing a new pattern for them to follow in the future) highlights its supervisory role in the various areas of law; the frequency of reversal demonstrates which of the provincial courts of appeal have tended to be the closest to what the Supreme Court would establish as the judicial centre of gravity. Such an investigation is particularly valuable because it is during the last two decades that the Supreme Court has finally emerged from obscurity to provide the vigorous (and not always uncontroversial) judicial leadership that had long been expected from it. ${ }^{7}$

One should not, of course, render reversal too innocuous, or imply that provincial appeal courts and their relevant publics are indifferent to what happens when their cases are taken before the Supreme Court. Any individual judge or panel of judges seeks as a matter of course to deliver the best possible decision under the law in the specific dispute being resolved, but they do so with every hope and expectation that the merits of that decision and the persuasive rigor of the written reasons will carry the higher court as well should the case be taken to further appeal. The more often this is not the case, the more doubts are engendered (self- as well as public).

At the most practical level, one component of the value of citing the decision of a specific court of appeal in a specific case is the likelihood or unlikelihood of the decision subsequently being over-ruled by the Supreme Court of Canada. This question of that status and standing of a particular court of appeal is recurrent; there is some suggestion that a string of reversals at the hands of the Supreme Court of Canada was a major reason for the pressure on Manitoba's Chief Justice Prendergast to resign in the $1940 \mathrm{~s},{ }^{8}$ and more recently the French-language network Radio Canada provoked considerable controversy by comparing the reversal rates of the Ontario and Quebec Courts of Appeal in recent terms, much to the discredit of the latter. Although there is no simple or automatic connection between reversal and merit, it would be equally unrealistic to

5.

To be sure, this is not as large a consideration now as it was fifty or so years ago, when the individual and collective performance of the judges of the Supreme Court was much weaker.

6. The reference being to such developments as the creation of specialized appeal courts in the last two of the ten provinces; the expansion of Supreme Court's discretionary leave jurisdiction; the highprofile and politically controversial Laskin Court; and the constitutional entrenchment of the Charter.

7. See, e.g., J.G. Snell and F. Vaughan, The Supreme Court of Canada: History of the Institution (Toronto: Osgoode Society/University of Toronto Press, 1985), esp. Ch. 10.

8. D. Gibson and L. Gibson, Substantial Justice: Law and Lawyers in Manitoba, 1670-1970 (Winnipeg: Peguis Publishers, 1972) at 282. 
suggest a complete separation between the two in the eyes of other judges, lawyers, and the wider public.

\section{STATISTICAL OVERVIEW}

Between March 23, 1970 and June 30, 1990, ${ }^{9}$ the Supreme Court of Canada delivered 1725 reported decisions on appeals from the various provincial courts of appeal, these comprising 84.5 per cent of the Supreme Court caseload over the period. ${ }^{10}$ The Supreme Court allowed the appeal on 761 occasions $^{11}$ for a success rate of 44.1 per cent. 181 of those appeals were from the decisions of the Alberta Court of Appeal, of which 75 (41.4 per cent) were successful. Success rates ranged from a low of $\mathbf{3 7 . 5}$ per cent for British Columbia to a high of 52.3 per cent for Saskatchewan and 54.2 per cent for the four Atlantic provinces combined. ${ }^{12}$

For two reasons, this figure almost certainly understates the extent of Supreme Court supervision and intervention in provincial appeal court decisions. First, it includes only Supreme Court reversals on direct appeal. It is also possible for the Supreme Court to refer to a provincial appeal decision in the course of another case as a precedent that is not to be followed; such collateral reversal is not included in this discussion. Second, the Supreme Court may uphold the result of the provincial appeal, but significantly alter the grounds on which that result is legally justified. For example: in Black v. Law Society of Alberta ${ }^{13}$ the Supreme Court upheld the Alberta Court of Appeal but shifted the focus of the case from Section 2 of the Charter (freedom of association) to Section 6 (mobility rights). There has been no attempt in this analysis to code for this more subtle type of supervision and correction.

At first glance, this reversal rate seems rather high, the more so as provincial appeal decisions are (with the statistically infrequent exception of reference cases) themselves panel reconsiderations of trial court decisions; one would expect that straightforward reversal for error (for example) would be negligible on the second screening. It is rather disconcerting to find that a provincial appeal court decision is almost as likely to be

9. This somewhat awkward period of twenty years and three months is selected because it comprises the complete term of office of three successive Chief Justices of Canada: Fauteux (1970-73), Laskin (1973-84) and Dickson (1984-90).

10. The other elements of the caseload were appeals from other federal courts (13.4\%), per saltum appeals direct from S.96 trial courts $(0.7 \%)$, rehearings $(0.6 \%)$, appeals from federal boards $(0.5 \%)$ and reference cases $(0.2 \%)$. Statistics based on all cases reported in Supreme Court Reports for the years 1970 through 1990.

11. Including appeals "allowed in part," the critical question being whether or not the Supreme Court altered the resolution of the case delivered in the court below. In the language suggested by Burton Atkins, both outcomes represent interventions by the higher court into the decision of the lower court. See "Interventions and Power in Judicial Hierarchies: Appellate Courts in England and the United States" (1990) 24 Law and Society Review.

12. For convenience, the figures from the four Atlantic provinces will be combined throughout this study, partly because the numbers of appeals from some of the provinces are so small that the figures can be misleading, and partly because two of the Atlantic provinces acquired full-time specialized courts of appeal only during the time period considered.

13. (1989), 58 D.L.R. (4th) 317 
reversed as upheld upon subsequent reconsideration by a higher court, the more so as that court is composed almost entirely of judges elevated from the provincial courts of appeal. ${ }^{14}$ However, such concern misapprehends the function of a general court of appeal in a hierarchical system. Since December 1974 - that is, for three-quarters of the period considered - the Supreme Court has exercised a substantial discretionary control over its own caseload, ${ }^{15}$ screening out less important cases to allow it to focus on major legal issues of national concern. If the three hundred or so refused applications for leave are considered to be dismissals of a sort (in the sense that they represent a refusal to intervene in the lower court's resolution of the dispute), then the overall appeal success rate would be much lower, and the question is rather why the Supreme Court intervenes to change the outcome so seldom.

By way of comparison, the success rate of appeals to the Supreme Court of the United States in recent decades has been much higher, at 66.1 per cent, ${ }^{16}$ although the comparison should be taken with a grain of salt because the two situations are not strictly comparable; this similarity of names exaggerates the extent to which there is a similarity of function. Judges of the U.S. federal and state courts are not (while those of the Canadian Supreme and provincial appeal courts are) selected by the same political elites from the same legal communities; the U.S. court system therefore contains a structural predisposition toward conflict and confrontation that is absent from the Canadian system.

\section{FREQUENCY OF APPEALS}

With (just under) one-tenth of the Canadian population, the Alberta Court of Appeal contributes (just over) one-tenth of the appeals from provincial courts of appeal that made up the Supreme Court caseload over the two decades. However, any attempt to extrapolate from this observation to a theory linking appeal rates to population size fails immediately - the Manitoba Court of Appeal has generated far too many, and the Ontario Court of Appeal far too few, appeals for this to hold. Table 1 presents a breakdown in terms of the number of appeals per 100,000 of population over the twenty-year period.

14. In the last twenty years, the only members of the Supreme Court without prior judicial experience have been Justices de Grandpre and Sopinka. Justices Le Dain and Iacobucci were elevated from the Federal Court of Canada.

is. But not yet a complete discretionary control. Bushnell suggests that further amendments to the Supreme Court Act that would have "dropped the other shoe" by further extending discretionary leave jurisdiction were twice introduced but never passed by the Commons, and he suggests that this must be read as something less than a vote of confidence in the Supreme Court. See S.I. Bushnell, "Leave to Appeal Applications: The 1985-86 term" (1987) 9 Sup. Ct. L. Rev. 467. 
Table 1: Appeal Rates, by Population

Appeals from Provincial CAs to SCC, 1970 to 1990

\begin{tabular}{||l||c|c|c||}
\hline Province & Appeals & Population* & $\begin{array}{l}\text { Appeals per } \\
100,000\end{array}$ \\
\hline \hline B.C. & 251 & 2,744 & 9.1 \\
\hline Alberta & 181 & 2,238 & 8.1 \\
\hline Sask. & 86 & 968 & 8.9 \\
\hline Manitoba & 124 & 1,026 & 12.1 \\
\hline Ontario & 471 & 8,625 & 5.5 \\
\hline Quebec & 446 & 6,438 & 6.9 \\
\hline Atlantic** & 166 & 2,234 & 7.4 \\
\hline ALL CAs & 1725 & 24,343 & 7.1 \\
\hline \hline
\end{tabular}

* population in thousands, 1981 census

** $\quad$ figures from four Atlantic provinces combined; includes appeals from provincial Supreme

Courts en banc

Alberta falls very close to the all-province average; the difference amounts to only one case per year. Manitoba stands out as the single province contributing disproportionately to the Supreme Court caseload, generating the number of appeals that one would expect from a province of almost two million. Ontario, at the other extreme, gives rise to comparatively few appeals (with some 150 cases less than its notional share over the period). For these two extremes, there is some apparent logic to the pattern: Manitoba, with a high rate of reversal, is frequently appealed, while Ontario, with a very low rate of reversal, is appealed relatively seldom. This rationale cannot be extended more broadly, however; the British Columbia Court of Appeal is appealed more often than average, but has the lowest reversal rate of all provinces since 1970, while the Quebec Court of Appeal combines a high reversal rate with a low appeal rate.

To be appealed, of course, is to be subject to review, criticism and reversal; from this point of view, it is perhaps a negative thing that the four western courts of appeal contribute disproportionately to the Supreme Court caseload. But the reversal rates in the Supreme Court refute any notion that the western courts of appeal (especially those of British Columbia and Alberta) are appealed so often because they do a particularly poor job; instead, the frequency of appeal seems curiously unconnected to interprovincial differences in the likelihood of success.

This being the case, there is another aspect of the matter to be considered. The decisions of the western courts of appeal hold up very creditably on review - but every 
time there is such an appeal, the Supreme Court is exposed to the assumptions and the ideas and the vision of those appeal court judges. The more competent and persuasive those judges, the greater the potential impact upon the Supreme Court. The classic example is the dissent of Freedman C.J.M. in Dominion News, ${ }^{17}$ adopted by the Supreme Court when they reversed the decision of the Manitoba Court of Appeal; the fact that the case was brought before them on appeal surely increased the attention the Court directed to Freedman's legal ideas and the way he framed the issues.

If there are specific regional issues, or specific regional dimensions to more pervasive issues, the flow of cases up through the provincial court systems to the Supreme Court is a flow of the specific information that the judicial system employs to devise an appropriate response. Table 1 can therefore be seen in a more positive light as demonstrating that the western courts of appeal have contributed disproportionately to the cases with which the Supreme Court of Canada has fashioned its judicial vision: western cases make up 37\% of the caseload, compared with $27 \%$ for Ontario, $26 \%$ for Quebec, and only $10 \%$ for the four Atlantic provinces.

(At the same time, the rising caseload of the provincial courts of appeal, and the shrinking caseload of the Supreme Court under the impact of the Charter, have made review rather infrequent in overall terms. One provincial appeal decision in 80 is appealed to the Supreme Court, and only one in 200 is reversed. ${ }^{18}$ )

\section{LASKIN AND THE OTHERS: SUCCESS RATES PAST AND PRESENT}

The single number indicating success rates over a twenty year period can be misleading, because it suggests as static the product of a number of dynamic variables. There is a steady turnover on provincial courts of appeal and the Supreme Court itself, ${ }^{19}$ the role of the courts has recently undergone dramatic changes, and the society from which arise the disputes the courts must resolve has itself been far from static. Constancy must be demonstrated; it cannot simply be assumed.

The obvious and periodization is provided by the three Chief Justiceships of the Supreme Court of Canada: Fauteux (March 23, 1970 to December 22, 1973); Laskin (December 27, 1973 to March 26, 1984) and Dickson (April 9, 1984 to June 30, 1990). ${ }^{20}$ This is, of course, convenient rather than rigorous, because a new Chief Justice typically represents a simple "double shuffle" (puisne judge to Chief, the vacancy being made good by the appointment of a new puisne judge $)^{21}$ while the rest of the court remains the

\footnotetext{
17. Dominion News and Gifts Ltd. v. The Queen, [1964] S.C.R. 25.

18. Comments based on research in progress.

19. Although we have been appointing on average one new Supreme Court judge a year since 1970, double the rate for the previous ninety-five years.

20. The results would be similar if the periodization were derived from the Chief Justiceship of the Alberta Court of Appeal rather than the Supreme Court of Canada, the term of McGillivray C.J.A. (December 5, 1974 to December 16, 1984) coinciding reasonably closely with that of Laskin C.J.C.

21. In principle, an individual from outside the Court could be appointed directly to the Chief Justiceship. but this is not the normal practice; only one (Fitzpatrick) of the fifteen Chief Justices appointed since the initial staffing of the Court was not already a puisne judge of the Court.
} 
same, but it has more to recommend it than (say) an arbitrary division by decades. There can be no doubt whatever that the distinguished and controversial Laskin left his personal mark on the decisions of the Court that he led; and commentators have described the Dickson Court as possessing "a collegial personality more distinctive than that of any of its previous incarnations...."22 This being the case, it seems reasonable to treat each Chief Justiceship as a separate period.

Table 2: Success Rates, by Province and SCC Chief Justice Appeals from Provincial CAs to SCC, 1970 to 1990

\begin{tabular}{||l||c|c|c|c||}
\hline Province & Fauteux & Laskin & Dickson & All \\
\hline \hline B.C. & $43.9 \%$ & $40.0 \%$ & $31.1 \%$ & $37.5 \%$ \\
\hline Alberta & $41.4 \%$ & $48.4 \%$ & $31.1 \%$ & $41.4 \%$ \\
\hline Sask. & $58.3 \%$ & $59.5 \%$ & $40.6 \%$ & $52.3 \%$ \\
\hline Manitoba & $37.5 \%$ & $58.3 \%$ & $45.8 \%$ & $50.8 \%$ \\
\hline Ontario & $43.8 \%$ & $41.5 \%$ & $27.5 \%$ & $38.0 \%$ \\
\hline Quebec & $45.2 \%$ & $45.0 \%$ & $57.5 \%$ & $48.2 \%$ \\
\hline Atlantic* & $64.7 \%$ & $52.5 \%$ & $54.2 \%$ & $54.2 \%$ \\
\hline All CA's & $45.5 \%$ & $46.0 \%$ & $40.0 \%$ & $44.1 \%$ \\
\hline
\end{tabular}

* figures from four Atlantic provinces combined; includes appeals from provincial Supreme Courts en banc

The success rates for appeals to the Supreme Court have in fact varied dramatically from one Chief Justiceship to another. Overall, the Laskin Court was slightly more ready, and the Dickson Court significantly less ready, than the Fauteux Court to reverse a provincial appeal decision. This pattern is replicated very dramatically by appeals from the three prairie provinces, although the success rates for appeals from B.C., Ontario and the Atlantic region decrease steadily through the three periods, while Quebec shows exactly the obverse of the overall pattern: a slight decrease in success rates as we move from the Fauteux Court to the Laskin Court, with a striking jump in success rates for the Dickson Court. Too many patterns carry little more meaning than no pattern at all; on the face of it, Table 2 suggests the connection between outcome by province and the chief justiceship may be close to random. 
Table 3: Success rates by Province and Type of Law Appeals from Provincial CAs to SCC, 1970 to 1990

\begin{tabular}{||l||l|l|l|l||}
\hline \hline Province & $\begin{array}{l}\text { appeal } \\
\text { success\% }\end{array}$ & $\begin{array}{l}\text { crim. } \\
\text { success\% }\end{array}$ & $\begin{array}{l}\text { private } \\
\text { success\% }\end{array}$ & $\begin{array}{l}\text { public } \\
\text { success\% }\end{array}$ \\
\hline \hline B.C. & $37.5 \%$ & $35.0 \%$ & $44.8 \%$ & $34.4 \%$ \\
\hline Alberta & $41.4 \%$ & $32.6 \%$ & $48.2 \%$ & $51.3 \%$ \\
\hline Sask. & $52.3 \%$ & $27.3 \%$ & $68.8 \%$ & $66.7 \%$ \\
\hline Manitoba & $50.8 \%$ & $32.8 \%$ & $74.2 \%$ & $62.5 \%$ \\
\hline Ontario & $38.0 \%$ & $23.6 \%$ & $48.0 \%$ & $47.7 \%$ \\
\hline Quebec & $48.2 \%$ & $47.4 \%$ & $50.2 \%$ & $45.9 \%$ \\
\hline Atlantic* & $54.2 \%$ & $60.4 \%$ & $50.0 \%$ & $52.8 \%$ \\
\hline ALL & $44.1 \%$ & $34.6 \%$ & $51.0 \%$ & $48.1 \%$ \\
\hline
\end{tabular}

* figures from four Atlantic provinces combined; includes appeals from provincial Supreme Courts en banc

But simply considering the success rate for all appeals is potentially misleading. Not all appeals are of a kind, and appeals for different types of law are not equally likely to succeed. Table 3 compares the success rates of appeals from the various provinces for three basic categories: first, criminal appeals; second, private law appeals; and third, public law appeals. ${ }^{23}$

Over the last twenty years, private law appeals have been half again as likely to succeed as criminal law appeals, and public law appeals have been only modestly less successful than private law appeals; one criminal appeal in three, but one private or public appeal in two, is successful. This pattern is roughly similar for Ontario and for the four Western provinces (although the absolute levels and the steepness of the differences shows some variation); for Quebec, the success rates for all three types of appeal are roughly similar, while criminal appeals from the Atlantic region are more likely to succeed than other appeals from the same courts.

At the same time, the mix of the various types of law within the Supreme Court caseload has clearly not remained constant during the two decades; quite the contrary.

23. Here defined as non-criminal cases to which a government official or board or department acting in that capacity is a party. The term "public law" is often used to include criminal law as well; the more restrictive use is the stipulative definition that will be employed for this study. 
Many commentators ${ }^{24}$ have noted the diminishing presence of private law appeals to the Supreme Court, a change which predates the Charter but has been accelerated by that significant alteration of the judicial role. Given the persisting differences in the success rates for the various types of appeals, it follows that simply changing the proportions of the various types of appeal within the Supreme Court caseload can dramatically alter overall success rates, especially if the relative share of less-often successful criminal appeals changes dramatically. ${ }^{25}$

Table 4 statistically summarizes these proportions for the periods of each Chief Justiceship. The pattern is consistent and cumulative: public law appeals have accounted for a fairly consistent one quarter of the Supreme Court caseload, but the ratio between private law and criminal law appeals has swung from three to one in favour of the former for the Fauteux court to three to one in favour of the latter for the Dickson court. The real difference between the Dickson Court and its forerunners is less that the Dickson court is markedly less prepared to reverse the provincial appeal court decision, than that the Dickson court has handled a much higher proportion of the criminal appeals that the Supreme Court has always been less ready to reverse.

\section{Table 4: Type of Law as Proportion of Total Caseload, by Supreme Court Chief Justice Appeals from Provincial CAs to SCC, 1970-1990}

\begin{tabular}{||c||c|c|c||}
\hline $\begin{array}{c}\text { Chief Justice } \\
\text { SCC }\end{array}$ & $\begin{array}{c}\text { Criminal } \\
\text { appeals }\end{array}$ & $\begin{array}{c}\text { Private law } \\
\text { appeals }\end{array}$ & $\begin{array}{c}\text { Public law } \\
\text { appeals }\end{array}$ \\
\hline \hline Fauteux & $19.1 \%$ & $55.3 \%$ & $25.7 \%$ \\
\hline Laskin & $32.5 \%$ & $39.4 \%$ & $28.1 \%$ \\
\hline Dickson & $54.1 \%$ & $20.3 \%$ & $25.6 \%$ \\
\hline TOTAL & $37.0 \%$ & $35.9 \%$ & $27.0 \%$ \\
\hline
\end{tabular}

To identify properly the changes that have occurred over the two decades, the reversal rates must be corrected to account for the changes that have occurred in the proportions of the various types of appeal. For the period of each Chief Justiceship (and for each province) the success rate for each type of case can be applied to a hypothetical mix of cases that exactly parallels the proportions of the three types for the Supreme Court's twenty-year caseload (37\% criminal, $36 \%$ private, $27 \%$ public). Without this, there can

For example: P. Monahan, Politics and the Constitution: The Charter, Federalism and the Supreme Court of Canada (Toronto: Carswell/Methuen, 1987), esp. Ch. 1 "Changing the Court's Business"; and D. Gibson, "The Crumbling Pyramid: Constitutional Appeal Rights in Canada" 38 U.N.B. L. J. 1 .

25. In principle, correcting for this same factor could also dramatically alter the relative performance of the various courts of appeal, but in practice the differences are modest. 
be no distinction between a court that seldom reverses and a court with an unusually high proportion of criminal cases, or between a court that often reverses and a court with a large number of private law appeals. A comparison of the results for Alberta appeals and for all other appeals are shown in Table 5.

Table 5: Corrected Success Rate, Alberta vs. All Other CAs by Supreme Court Chief Justice, 1970-1990

\begin{tabular}{||c||c|c|c||}
\hline Chief Justice & $\begin{array}{c}\text { Alberta } \\
\text { CA }\end{array}$ & $\begin{array}{c}\text { All other } \\
\text { CAs }\end{array}$ & $\begin{array}{c}\text { Total } \\
\text { CAs }\end{array}$ \\
\hline \hline Fauteux & $41.6 \%$ & $42.5 \%$ & $42.4 \%$ \\
\hline Laskin & $48.8 \%$ & $45.0 \%$ & $45.4 \%$ \\
\hline Dickson & $34.7 \%$ & $44.5 \%$ & $43.5 \%$ \\
\hline TOTAL & $43.2 \%$ & $44.3 \%$ & $44.1 \%$ \\
\hline
\end{tabular}

The appearance of lower success rates for appeals to the Dickson Court than to the Laskin Court is in fact entirely an artefact of the shifting proportions of the different types of appeal. Once this gratuitous effect is eliminated, the picture is rather different. There seems to have been a slight but enduring long-term increase in success rates between the Fauteux Court and Laskin Court, with the Dickson Court following the latter very closely. The direction of this shift is what one would expect from the expanded discretionary jurisdiction of the Supreme Court - that is, the cases that are no longer decided by the Supreme Court because of the power to refuse leave to appeal tend to include a number of routine appeals that would have been dismissed; the outcome for the individual parties is the same as if the case had been heard and summarily dismissed, but the statistics on reversal rates are altered in the process. If anything is surprising, it is that the effect of this change is not larger - that is, that the discretionary exclusion of routine appeals has not sharply reduced the numbers of dismissed appeals while roughly maintaining the number of reversals.

But for Alberta appeals, ${ }^{26}$ nothing is explained away by correcting the success rates, and the apparent initial pattern is simply confirmed: reversal rates were slightly below the all-province average under the Fauteux court, soared dramatically at the hands of the Laskin court, and then plummeted sharply under the Dickson court.

There are two different ways in which one might explain this development. The first is that a new set of Supreme Court judges reversed a cross-section of Alberta appeal judges more readily than they reversed the continuing members of the court; this does not seem to be borne out by the numbers. In the first five years of the Laskin court, continuing judges voted to reverse ${ }^{27}$ the Alberta Court of Appeal 51.2 per cent of the

26. And, incidentally, for appeals from the other Westem provinces as well.

27. That is, they concurred with a decision to reverse, or dissented from a decision to uphold. 
time, while "new" judges (Laskin and those appointed after him) did so 50.2 per cent of the time. The differences are small, and the direction is the reverse of what would have been expected.

The second possibility is that a new set of Alberta appeal judges found themselves more out of step with the Supreme Court, evidence by the fact that they were over-ruled by a cross-section of the Supreme Court more frequently than the continuing members of the Alberta court; the numbers seem to support this more strongly. The judges of the Supreme Court voted to reverse "continuing" judges of the Alberta Court of Appeal 47.8 per cent of the time, compared to 52.4 per cent for "new" judges (taking the appointment of Mr. Justice Prowse in $1972^{28}$ as the dividing point). The shift in appellate success rates therefore seems to be linked more to personnel changes in the provincial Court than to those in the Supreme Court. A similar analysis of the figures for the Dickson court and the last five years of the Laskin court is inconclusive.

\section{CORRELATES OF SUPREME COURT REVERSAL}

It seems intuitively obvious (which is not to say that it is true) that a dissenting opinion in the appeal court judgment makes both further appeal and Supreme Court reversal more likely. The logic is obvious: if the issues in the case are sufficiently difficult or controversial that even the appeal court panel cannot agree on its disposition, then it is that much more likely that a majority of the Supreme Court will also be unable to agree with the appeal court majority. (At a more pragmatic level, it may also be the case that, other things being equal, a non-unanimous appeal court decision attracts special attention from the Supreme Court, while a vigorously argued dissent may provide an early focus around which doubts may coalesce.)

The Alberta Court of Appeal is, on the evidence of recent years, one of the more consensual of the provincial courts of appeal, less likely than (say) Manitoba or Quebec to yield a non-unanimous decision. ${ }^{29}$ Nonetheless, fifty-one of the 167 appealed decisions for which information was available were made over the dissents of one or more of the Alberta appeal judges on the panel. This relatively high proportion (almost onethird of appealed decisions, as against less than one-tenth of all reported decisions) clearly supports the conventional wisdom that dissents spur further appeals. Equally, the success rates confirm the expectations that lie behind that conventional wisdom; appeals from nonunanimous decisions succeed 47.1 per cent of the time, compared with 41.4 per cent for unanimous decisions.

The direction of the difference makes sense; the magnitude is mildly surprising, given that in criminal cases a dissent on a question of law creates an appeal by right to the

28. Since 1970 it has taken on average twenty-one months for a case to rise from the Alberta Court of Appeal to the Supreme Court, which makes it useful to put the cut-off point between "continuing" and "new" judges slightly earlier for the Court of Appeal.

29. For a comparison of the dissent rates of the Westem provincial courts of appeal in recent years, see McCormick, "Caseload and Output of the Manitoba Court of Appeal 1989," (1991) 20 Man. L. Rev. (forthcoming). 
Supreme Court. In other words, it by-passes the screening function of expanded leave jurisdiction, and obliges the Supreme Court to deliver a decision on a case it might otherwise have refused to hear as inconsequential or routine. The recent Supreme Court Reports are strewn with one-paragraph dismissals of this sort, depressing the success rate of appeals from non-unanimous decisions, and thereby suggesting that the success rate for the less trivial examples of this category must be that much higher.

It has also been suggested in the literature ${ }^{30}$ that reversal is more likely for an appeal decision that reverses the original trial decision than for an appeal decision that affirms it; certainly this is the pattern that can be observed in the U.S. data. The logic here is not quite so obvious, but runs as follows: the ideal outcome of a series of appeals, other things being equal, is for the various levels of court to agree on the appropriate resolution of a specific case. This is the ideal because it reduces the appearance of a "luck of the draw" factor that highlights individual judicial discretion, and presents instead the image of an objectively correct answer which is obvious to all trained professionals. Once the intermediate appeal court has (so to speak) rippled the surface of the water by reversing the trial judge, the final appeal court is that much less reticent to intervene itself by changing the outcome again.

Of the cases appealed beyond it to the Supreme Court of Canada, the Alberta Court of Appeal had itself allowed the appeal 93 times, and dismissed it 85 times. ${ }^{31}$ (There were also three reference cases that could not be identified with either category.) The success rate in the Supreme Court for appeals that reversed the trial judge's decision was just over $50 \%$ (47 of 93); the success rate for appeals affirming the trial decision was just over $30 \%$ (27 of 85). The direction of the difference is what the U.S. data would lead us to expect, and the size of the difference is striking; the predictive value of knowing whether the provincial appeal court itself had allowed or dismissed the appeal is greater than knowing whether or not the decision was unanimous.

If these two variables are indeed correlated with Supreme Court reversal rates, then it should be possible to combine them to create four different levels of likelihood. The Supreme Court looked at 47 cases in which the Alberta court had unanimously dismissed an appeal, and reversed the Alberta court only 30 per cent of the time; for the 32 cases in which the Alberta court had non-unanimously dismissed an appeal, it reversed 37.5 per cent. 68 times the Alberta court unanimously reversed a trial decision, and was itself reversed on further appeal 50 per cent of the time. Finally, there were 17 cases in which the Alberta court non-unanimously reversed the trial judge; the success rate of further appeals was 65 per cent. The gradient is striking, and suggests that the variables do have predictive value. ${ }^{32}$

31. This, of course, overstates the success rate of appeals to the Alberta Court of Appeal, which in recent years is below $40 \%$.

32. Indeed, the gradient is so consistent and striking that we can express it in mathematical terms, as follows: Both dissents and reversals of the trial decision, are " + " factors for an appeal from the decision of a provincial court of appeal. If neither " + " factor applies, appeals succeed $25 \%$ of the time; if there is only one " + " factor, appeals succeed $45 \%$ of the time; if both " + " factors are present, the success rate is $65 \%$. 


\section{WHO VOTES TO REVERSE? \\ THE JUDGES OF THE S.C.C. AND ALBERTA APPEALS}

One of the Supreme Court decisions on Alberta appeals was per coram (that is, anonymous and unanimous); the 180 other decisions were delivered by twenty-one different judges. Data on panel appearances ${ }^{33}$ and delivered opinions are presented in Table 6. The trio of Martland, Laskin and Dickson clearly dominates, between them delivering more than one-half of the decisions. Four other judges (Ritchie, McIntyre, Lamer and Estey) delivered ten or more decisions, this accounting for another one-quarter of all decisions; no judge other than these seven delivered more than half a dozen decisions.

What stands out is the extremely low profile of the French Canadian judges (that is, the nine Quebec judges excluding Abbot, plus Le Dain and La Forest). In a total of 395 panel appearances (almost one third of the total), these eleven judges delivered only 27 decisions (or less than one-sixth); that is, French Canadian judges deliver less than half as many decisions as one would expect from a purely random rotation. At the other extreme, the five Western judges, with just over a quarter of the panel appearances (329) delivered almost one-half of the decisions (85) - almost double what one would expect to find at random.

To consider things from a different angle: the 181 Supreme Court decisions resulting in seventy-five reversals can be considered as a string of votes by individual Supreme Court justices for or against the decision of the Alberta Court of Appeal. This viewpoint is slightly distorting, because it is a critical feature of appellate decision- making that it issues from a collaborative and interactive process involving all members of the panel, not from the recording of a discrete series of decisions arrived at privately and independently; with this reservation, however, the numbers can still be useful. Table 6 also indicates (for criminal appeals, public law appeals and private law appeals) the percentage of "negative" votes - a vote to reverse the Alberta appeal decision, either by joining the decision of the Court or delivering a separate concurrence for an allowed appeal, or by dissenting from a dismissed appeal - by each Supreme Court judge. Asterisks indicate percentages generated by fewer than six panel appearances of the relevant type.

One rather surprising correlation emerges very quickly: of the seven Supreme Court judges who are the least prepared to vote to reverse an Alberta decision, the only one not from Quebec is La Forest. It would be interesting to know if this is a feature of the Quebec judges' behaviour specifically on Alberta appeals, or on appeals from provincial courts generally. The trio most regularly voting against the Alberta appeal decision were Hall, Laskin and Spence (these three being the only Supreme Court judges with an overall negative voting percentage more than $10 \%$ above the average).

33. Cases for which a justice is listed on the panel but did not participate in the decision are excluded from these figures. 
Table 7 examines some crude objective measures of the types of Supreme Court judges most and least likely to vote against the Alberta Court of Appeal when those decisions are appealed further. The regional dimension is striking - judges from Quebec are the most likely to vote against reversing the Alberta Court of Appeal. This is most pronounced in (the dwindling category of) private law appeals, where they stand apart from all other groups of judges; they are joined by judges from the Atlantic provinces on public law appeals, and by both Atlantic and Western judges on criminal appeals. The strongest and most consistent voting to reverse the Alberta court comes from those Supreme Court judges from Ontario. Judges elevated from the provincial courts of appeal are more likely to vote to reverse than judges appointed (as the rather quaint phrase has it) "from the street;" Liberal appointees are more like to do so that Conservative appointees. The two ends of the polarity can be personalized in (say) Chouinard and Laskin.

The point of including on the table the voting patterns of appointees of four of the last six Prime Ministers is to illuminate changes over time, not to impute any direct prime ministerial influence or intentional policy. Alberta's reversal rate on criminal appeals is, generally speaking, declining fairly steadily over the period; the fact that reversal rate on private law trends sharply upward should probably be seen as the product as much or more of greater selectively by the Supreme Court ${ }^{34}$ than of any change in objective competence. Public law reversals rose under the influence of the Trudeau appointees, but are dramatically down for the Mulroney appointees. Should this trend persist (the qualification is important, because the numbers at present are still small, and the unusually and persistingly high turnover rates on the Court make extrapolation difficult), Alberta precedents would in the future be increasingly valuable in public as well as criminal law jurisprudence $\mathrm{e}^{35}$ - valuable, that is, in the sense of providing a useful indication of what the Supreme Court position is likely to be when similar questions come before them.

\section{WHO GETS REVERSED?}

\section{THE JUDGES OF THE ALBERTA COURT OF APPEAL AND THE S.C.C.}

The 181 appealed decisions of the Alberta Court of Appeal were delivered by 22 different judges. ${ }^{36}$ Only six of these judges (Clement, McGillivray, Lieberman, Prowse, McDermid and Kerans) delivered ten or more appealed decisions, Clement leading the way with 20. Thirteen of the others delivered six appealed decisions or less. This being the case, it is hardly useful to generate a long list of these names with the small numbers of reversals and dismissals juxtaposed. Nor can the data usefully be broken down in terms of the Prime Minister who appointed the judge appealed from, as appointees of

That is, more rigorous screening as caseload pressures cut against permitting an extensive private law docket.

35. The limitation of statistical analysis, of course, is that it cannot tell us whether the reversal rates have dropped because the Alberta Court has come more in line with established Supreme Court doctrine, or whether the position of the Supreme Court itself has shifted with the influx of new personnel.

36. Excluding the single per coram decision, the two unanimous decisions delivered without written decision, the single decisions by a Court of Queen's Bench judge sitting as an ad hoc member of the Court of Appeal, and the eighteen decisions for which this information was not available. 
Pierre Trudeau alone delivered more than two-thirds of the decisions for which data is available, and Liberal appointees in total more than three-quarters. For eleven of the judges, the appeal bench represented their first judicial appointment, while the other half were elevated from the trial bench (averaging just over seven years of such experience), but this made little difference to the rate of success on appeal $(41.7 \%$ and $40.7 \%$ respectively), or to the frequency of appeal ( 0.6 appeals per judge per year to 0.5 appeals per judge per year).

One hypothesis that can be tested is that based on experience: that is, the suggestion that longer-serving provincial appeal judges have built up a personal background of experience and judgment that better allows them to understand and to anticipate Supreme Court decisions, and therefore will tend to be reversed on appeal less often than more recently appointed judges. (The counter-hypothesis, equally plausible on the face of it, would be that newly appointed judges tend toward caution but longer service generates increasing self-confidence and independence, resulting in a willingness to "call it as they see it" even at the risk of subsequent reversal at the hands of the Supreme Court; the null hypothesis would be that reversal rates are a function of individual competence, not experience, and therefore that the relationship between length of service and likelihood of reversal approaches randomness.)

Appealed Alberta decisions were divided into four categories, based on the length of time between appellate appointment and the delivery of the Alberta court of appeal decision. "Recently appointed judges" were defined as those who had less than five years of appellate experience before delivering the specific decision; "established judges" were those with more than five but less than ten years' experience; "senior judges" were those with more than ten but less than fifteen years' experience; and "very senior" judges were those who had served for fifteen years or more. ${ }^{37}$ The results, overall and then for elevations and first-time appointments separately, are presented in Table 8.

Overall, the Alberta data mildly supports the hypothesis that increasing length of experience goes with decreasing likelihood of reversal on appeal. ${ }^{38}$ The generalization is more firmly true of first-time judicial appointments, for whom the success rate on appeals drops very sharply after the first five years. This is entirely consistent with the idea that the role of a judge is a difficult and demanding one, requiring a breadth of vision and a wealth of experience that develops over a period of years, with a particularly critical initial transition period while the appropriate norms and procedures are learned.

For appeal judges elevated from the trial bench, however, the pattern is quite different, suggesting an initial period of reticence followed by increasing boldness and independence. The higher reversal rate for experienced judges with prior trial bench experience is somewhat counter-intuitive and refutes the simple but temptingly obvious

These categories are adapted from those suggested by R. Carp and R. Wheeler, "Sink or Swim: the Socialization of a Federal District Judge" (1972) 21 J. Pub. L. 359-393.

38. The results are roughly consistent (making some allowance for the smaller numbers involved) for all three types of appeal. 
generalization that length of judicial experience itself tends to reduce the likelihood of subsequent reversal.

Although the numbers are rather small, the reversal rate for "very senior" (15+ years) first-time appointees shows a slight increase, which suggests that there might be nothing more at work here than the simple fact that elevated judges have a several year head-start in judicial experience. Reworking the data in terms of judicial experience simpliciter (that is, combining both appellate and trial bench experience) permits a single generalization that embraces both elevated and first time appellate judges, in the following terms: appeal judges with five years or less of judicial experience tend to be reversed almost half the time $(47.2 \%)$, this falling by almost $10 \%$ for judges with five to fifteen years of experience, and then rising again to $50 \%$ for judges of fifteen or more years experience. A court-wide long-term reversal rate is modified by a phase-in period as new judges learn the ropes, and then subject to erosion as very senior judges display greater independence or (somewhat less charitably) drift out of touch with the new currents of judicial decisionmaking.

\section{SUMMARY OF FINDINGS}

The results of the statistical analysis of twenty years of appeals from the Alberta Court of Appeal to the Supreme Court of Canada can be summarized as follows:

1. The reversal rate for appeals from the Alberta Court of Appeal to the Supreme Court of Canada over the last two decades is $41.4 \%$, slightly below the allprovince average. The frequency of appeals, calculated per 100,000 of population, is slightly higher for Alberta than for all provinces combined, although lower than Manitoba or British Columbia.

2. Like most other provinces, appeals from the Alberta Court of Appeal succeed least frequently for criminal appeals, and most frequently for private law appeals. Success rates for public law appeals are almost as high as for private law appeals.

3. Recent changes in Supreme Court procedure, such as the increased discretionary leave jurisdiction, appear to have raised reversal rates only modestly; making allowance for the decline in private law appeals and the rise in criminal law appeals, overall reversal rates have been very consistent between the Laskin Court and the Dickson Court.

4. Reversal rates for appeals from the Alberta Court of Appeal rose significantly under the Laskin Court and dropped even more dramatically under the Dickson Court, a result that survives correction for the shifting proportions of the various types of appeals (specifically, the sharply declining frequency of private law appeals).

5. Appeals are more often successful from divided than from unanimous appeal court decisions; and more often successful when the appeal court reversed the 
trial judge than when it upheld the trial decision. These two influences are cumulative.

6. The majority of Supreme Court decisions on appeals from the Alberta Court of Appeal have been by the trio of Martland, Laskin and Dickson; more generally, Supreme Court judges from the West have delivered unusually many, and Supreme Court judges from Quebec unusually few, of the decisions on Alberta appeals.

7. The bloc of Supreme Court judges least likely to vote to reverse an Alberta decision is composed disproportionately of French-Canadian judges; the bloc of judges most likely to vote to reverse an Alberta decision is drawn significantly from Ontario.

8. Liberal appointees, and Supreme Court judges elevated from a provincial court of appeal, are more likely to vote to reverse an Alberta decision than Conservative appointees or Supreme Court judges without such prior experience.

9. The swing in the composition of Supreme Court caseload from private law to criminal law will tend to decrease the overall success rate of appeals, because the Supreme Court has tended to allow private law appeals much more often than criminal appeals. The Alberta reversal rate should also be pushed lower by the sharply reduced rate at which recent (Mulroney) appointees to the Supreme Court vote to reverse Alberta public law decisions.

10. There is an indication of a positive correlation between the length of experience of an Alberta Court of Appeal judge and the likelihood of reversal upon further appeal to the Supreme Court - the longer the judge has served, the lower the likelihood of reversal - but this is much more so for first-time judicial appointments than for the (recently more frequent) judges elevated from the trial bench. 
Table 6: Frequency of Votes To Reverse Alberta Court of Appeal

(Criminal, Public and Private Law Appeals)

Supreme Court of Canada Decisions, March 1970 to June 1989

\begin{tabular}{||c||c|c|c|c|l||}
\hline SCC Judge & $\begin{array}{l}\text { Decisions } \\
\text { Delivered }\end{array}$ & $\begin{array}{l}\text { Panel } \\
\text { Appear. }\end{array}$ & $\begin{array}{l}\text { crim } \\
\text { neg\% }\end{array}$ & $\begin{array}{l}\text { priv } \\
\text { neg\% }\end{array}$ & $\begin{array}{l}\text { pub } \\
\text { neg\% }\end{array}$ \\
\hline \hline Dickson & 29 & 126 & $31.2 \%$ & $56.7 \%$ & $53.1 \%$ \\
\hline Ritchie & 13 & 105 & $34.1 \%$ & $55.0 \%$ & $45.8 \%$ \\
\hline Martland & 34 & 100 & $36.8 \%$ & $52.4 \%$ & $45.0 \%$ \\
\hline Beetz & 3 & 88 & $35.6 \%$ & $50.0 \%$ & $47.4 \%$ \\
\hline Laskin & 29 & 81 & $43.8 \%$ & $64.7 \%$ & $66.7 \%$ \\
\hline McIntyre & 13 & 73 & $30.0 \%$ & $53.3 \%$ & $55.6 \%$ \\
\hline Lamer & 13 & 71 & $37.5 \%$ & $33.3 \%$ & $64.3 \%$ \\
\hline Spence & 4 & 70 & $46.2 \%$ & $58.1 \%$ & $53.8 \%$ \\
\hline Estey & 10 & 68 & $37.1 \%$ & $38.9 \%$ & $33.3 \%$ \\
\hline Wilson & 5 & 63 & $36.6 \%$ & $50.0 \%$ & $58.3 \%$ \\
\hline Pigeon & 3 & 50 & $41.7 \%$ & $55.6 \%$ & $12.5 \%$ \\
\hline Chouinard & 0 & 44 & $34.8 \%$ & $33.3 \%$ & $33.3 \%$ \\
\hline Judson & 1 & 43 & $47.1 \%$ & $44.4 \%$ & $37.5 \%$ \\
\hline L'Heureux-Dubé & 1 & 31 & $31.8 \%$ & $100 \% *$ & $33.3 \%$ \\
\hline La Forest & 2 & 31 & $35.0 \%$ & $50.0 \% *$ & $14.3 \%$ \\
\hline De Grandpré & 2 & 26 & $42.9 \%$ & $41.7 \%$ & $42.9 \%$ \\
\hline Hall & 5 & 20 & $66.7 \%$ & $72.7 \%$ & $66.7 \% *$ \\
\hline Abbott & 0 & 17 & $37.5 \%$ & $33.3 \%$ & $33.3 \% *$ \\
\hline Le Dain & 3 & 17 & $30.8 \%$ & $100 \% *$ & $0 \% *$ \\
\hline Sopinka & 0 & 14 & $33.3 \%$ & - & $50.0 \% *$ \\
\hline Cory & 16 & $40.0 \%$ & $50.0 \% *$ & $25.0 \%$ \\
\hline Gonthier & 14 & $27.3 \%$ & - & $66.7 \% *$ \\
\hline
\end{tabular}




\begin{tabular}{||l||c|c|c|c|c||}
\hline SCC Judge & $\begin{array}{l}\text { Decisions } \\
\text { Delivered }\end{array}$ & $\begin{array}{l}\text { Panel } \\
\text { Appear. }\end{array}$ & $\begin{array}{l}\text { crim } \\
\text { neg\% }\end{array}$ & $\begin{array}{l}\text { priv } \\
\text { neg\% }\end{array}$ & $\begin{array}{l}\text { pub } \\
\text { neg\% }\end{array}$ \\
\hline Pratte & 0 & 13 & $33.3 \%$ & $33.3 \% *$ & $0 \% *$ \\
\hline McLachlin & 4 & 10 & $40.0 \%$ & - & - \\
\hline Fauteux & 3 & 10 & $25.0 \%$ & $0 \% *$ & $0 \% *$ \\
\hline TOTAL & $180^{* *}$ & 1202 & $36.4 \%$ & $52.9 \%$ & $46.4 \%$ \\
\hline
\end{tabular}

* fewer than six panel appearances in category

* one SCC decision was per coram. 
Table 7: Votes To Reverse Alberta Court of Appeal, by Specific Attributes Supreme Court Decisions, 1970 to 1990

\begin{tabular}{|c|c|c|c|c|}
\hline & $\begin{array}{l}\text { Panel } \\
\text { Appear. }\end{array}$ & crim neg\% & priv neg\% & pub neg\% \\
\hline Maritimes & 136 & $34.4 \%$ & $54.5 \%$ & $38.7 \%$ \\
\hline Ontario & 373 & $39.5 \%$ & $54.8 \%$ & $49.3 \%$ \\
\hline Quebec & 364 & $35.9 \%$ & $45.9 \%$ & $41.1 \%$ \\
\hline West & 329 & $34.2 \%$ & $56.1 \%$ & $52.1 \%$ \\
\hline not $C A$ & 455 & $38.5 \%$ & $52.3 \%$ & $40.7 \%$ \\
\hline former CA & 747 & $35.4 \%$ & $53.5 \%$ & $49.7 \%$ \\
\hline $\begin{array}{l}\text { Liberal } \\
\text { appointee }\end{array}$ & 774 & $36.2 \%$ & $52.6 \%$ & $49.7 \%$ \\
\hline $\begin{array}{l}\text { Conservative } \\
\text { appointee }\end{array}$ & 428 & $36.7 \%$ & $53.5 \%$ & $40.4 \%$ \\
\hline $\begin{array}{l}\text { Diefenbaker } \\
\text { appointee }\end{array}$ & 268 & $39.2 \%$ & $54.1 \%$ & $45.5 \%$ \\
\hline $\begin{array}{l}\text { Pearson } \\
\text { appointee }\end{array}$ & 230 & $44.0 \%$ & $57.1 \%$ & $38.1 \%$ \\
\hline $\begin{array}{l}\text { Trudeau } \\
\text { appointee }\end{array}$ & 626 & $35.3 \%$ & $52.2 \%$ & $51.9 \%$ \\
\hline $\begin{array}{l}\text { Mulroney } \\
\text { appointee }\end{array}$ & 116 & $34.1 \%$ & $66.7 \%$ & $31.8 \%$ \\
\hline TOTAL: & 1202 & $36.4 \%$ & $52.9 \%$ & $46.4 \%$ \\
\hline
\end{tabular}




\section{Table 8: Success Rates of Appeals from Alberta Court of Appeal By Length of Experience of Judges Appeals to SCC from Alberta CA, 1970-1990}

\begin{tabular}{||l||c|c|c||}
\hline $\begin{array}{l}\text { Length of appellate } \\
\text { service }\end{array}$ & Elevated & $\begin{array}{c}\text { first } \\
\text { appointment }\end{array}$ & $\begin{array}{l}\text { all } \\
\text { judges }\end{array}$ \\
\hline \hline recently appointed & $(30) 40.0 \%$ & (33) $48.5 \%$ & $44.4 \%$ \\
\hline established judges & $(24) 45.8 \%$ & (40) $37.5 \%$ & $40.6 \%$ \\
\hline senior judges & $(7) 42.9 \%$ & (12) $33.3 \%$ & $36.8 \%$ \\
\hline very senior judges & - & (8) $50.0 \%$ & $50.0 \%$ \\
\hline TOTAL: & (61) $42.6 \%$ & (93) $41.9 \%$ & $42.2 \%$ \\
\hline
\end{tabular}

Note: information missing on name of judge and/or date of Alberta C.A. decision in 27 cases

\section{Methodological Appendix}

The decisions of the Supreme Court of Canada on which these comments and calculations are based were drawn from the Supreme Court Reports from 1970 to present, the cut-off point being defined by the date the decision was delivered, not the date it was reported. The reporting rate for Supreme Court decisions is (since 1970) close to $100 \%$, so possible distortion of the results because of the omission of some relevant cases from the Reports is not the problem it would be for a study reaching back before that date. Cases were coded as "allowed" or "dismissed"; appeals "allowed in part" were treated as "allowed", the critical question being whether the Court of Appeal decision did or did not remain as the final resolution of the legal issue. (This follows the usage of Burton Atkins, who uses the term "intervention.")

For each Supreme Court decision, all participating judges were recorded as delivering or joining the decision of the Court, or a dissent, or a separate concurring decision; judges listed as members of the panel but not participating were omitted from the calculations Decisions were coded as unanimous, majority or plurality. The series of votes by each individual judge were translated into "negative" or "positive" votes - that is, every concurring vote on a successful appeal, and every dissenting vote on an unsuccessful appeal, were taken as "negative" and similarly, mutatis mutandis, for "positive" votes.

Further information on each appealed decision of the Alberta Court of Appeal was collected and coded. This included the date of the Alberta decision, the judge delivering the decision, whether or not there was a dissent, and whether the Alberta Court of Appeal had itself allowed or dismissed the appeal. (Again, appeals "allowed in part" were counted as "allowed.") The initial expectation had been that any case important enough to be appealed to the Supreme Court was important enough to be reported (or at least 
became so by virtue of the appeal itself), but this turned out to be incorrect; in fact, about one-sixth of cases appealed from the Alberta Court of Appeal to the Supreme Court are not reported. Some of this information was collected from the docket books of the Alberta Court of Appeal for past years and from comments within the Supreme Court decision itself, but it is still incomplete. The incompleteness of data narrowed the enquiry; it made it impossible to see (for example) if the dissent of particular judges on the Alberta Court of Appeal tends unusually often to be vindicated by a Supreme Court reversal of the decision from which they dissented.

Information on the date of appointment of Alberta appeal court judges (including date of initial appointment for judges with prior judicial experience) is taken from an excellent unpublished study compiled by the Alberta Law Society in 1983, updated in 1985 . This uniquely valuable source has no counterpart in any other province. More recent data is from several sources, including (again) the recent records of the Law Society. The division into categories of experience is by exact calculation (that is, date of appointment subtracted from date of provincial appeal decision) rather than being grouped by calendar or court year.

Cases were coded as falling into one of three categories: criminal, public and private. The category of criminal cases is obvious and straightforward; public law cases were defined for present purposes as non-criminal cases to which the government, a government department or agency, or a government official in that capacity is a party. I apologize for any confusion caused by the fact that the term "public" law is often used as including criminal law, but I could not come up with any less problematic terminology. Private law cases (oversimplifying slightly but catching the core: disputes relating to torts and contracts to which only private individuals or commercial corporations are a party) make up the third category.

Data was collected and coding done by the author and by a graduate student research assistant; the categories were intentionally kept straightforward and nonjudgmental to maximize the usefulness to the profession of data collection and analysis by non-legally trained researchers. 